\title{
Kantian Dignity and Marxian Socialism
}

Pablo Gilabert (Concordia University, Montreal). Forthcoming in Kantian Review.

\section{Introduction}

The topic of the symposium to which this paper contributes, "Kant and Marx," may initially appear rather puzzling. Kant and Marx seem to operate in quite different registers: one was a moralist, the other was hostile to moral talk; one was a critic of feudalism, the other a foe of capitalism; one challenged despotism and proposed a state with a republican structure, the other called for the dissolution of the state; one praised obedience, the other revolution; one entertained a dualist picture of human beings as partly natural and partly non-natural entities, the other rejected any such dualism. One the other hand, there are significant similarities between these important thinkers: both had a progressive view of history as the expansion of human freedom; both praised self-determination and abhorred paternalism; both called for interpersonal and institutional arrangements in which people treated each other as ends and not merely as means; and both had a cosmopolitan view of the scope of the project of human emancipation.

In this paper, I identify a fresh and fruitful way to develop insights from both philosophers. I argue that we can articulate a Kantian conception of human dignity that helps to justify typically Marxian criticisms of capitalism as involving exploitation, domination, and alienation, and to develop the Marxian view of socialism as involving a combination of freedom and solidarity. Marx's own criticisms of capitalism and his occasional remarks on socialism are in need of normative structuring, which a Kantian conception of human dignity readily provides. That conception has great intuitive appeal, and it gains further support from noticing its explanatory power regarding the critique of capitalism and the defense of socialism. Kant's own account of dignity, on the other hand, should be modified to avoid an unnecessarily narrow view of the basis of human dignity only focused on rational freedom and an insufficient appreciation of some material and social aspects of human flourishing. Thus, a discussion of Kantian dignity and Marxian socialism will simultaneously feature revisions and criticisms of Kant's and 
Marx's contributions besides a discovery of important ways in which they can be used to support each other and to develop our own views.

This paper develops aspects of Kant's and Marx's work as powerful resources for a distinctive and appealing normative project, which I call Dignitarian Socialism. Kantian and Marxian insights help articulate two central ideas of this project, which I here state briefly, and develop as the paper proceeds. ${ }^{1}$

The first idea is that of the Dignitarian Approach, which holds that we have reason to organize social life in such a way that we respond appropriately to the valuable features of human beings that give rise to their dignity. To articulate a dignitarian approach, we need to provide an account of the following dimensions of it.

- Status-dignity; dignitarian norms; condition-dignity: Status-dignity is a normative standing of some entities such that agents who could affect them ought to treat them with appropriate respect and concern. I focus here on the treatment of human individuals by human agents. How exactly this respect and concern should be enacted is what dignitarian norms specify. Such norms sate various negative and positive duties. When these duties are fulfilled, human beings enjoy condition-dignity. The distinction between condition-dignity and status-dignity is crucial to avoid incoherent uses of the notion of dignity — as when some people are said to lack dignity because they are treated unjustly and to be entitled to a different, better treatment because of their dignity. ${ }^{2}$

- Basis of dignity: Human beings have status-dignity in virtue of some valuable features of them. An account of these features - the constituents of the basis of dignity-informs the articulation of dignitarian norms, as the content of those norms precisely tracks the appropriate responses to those features in various circumstances.

- Circumstances of dignity: The content of the dignitarian norms also depends on the problems they address. We can identify circumstances of dignity in which the dignitarian norms apply. These

\footnotetext{
${ }^{1}$ I offer a detailed discussion in Gilabert (forthcoming).

${ }^{2}$ Unless disambiguation is necessary, I will use "dignity" to mean status-dignity.
} 
circumstances can be more or less general (and the same goes for the norms addressing them), and they include problems warranting feasible and desirable responses in which dignitarian treatment is enacted.

- Social ideals, projects, enacting dignitarian treatment. Dignitarian norms can orient agents acting in the real world by constituting a dignitarian social ideal or project. Agents can, and should, act in such a way that they generate and sustain personal and institutional frameworks in which dignitarian treatment is enacted.

These dimensions of a Dignitarian Approach could of course be articulated in many ways, yielding different dignitarian conceptions. I am particularly interested in a conception that develops the idea of Solidaristic Empowerment, according to which we should support everyone's autonomous pursuit of a flourishing life by affirming both negative duties not to destroy or block their valuable human capacities and positive duties to protect and enable their development and exercise. This second idea is the moral core of Dignitarian Socialism.

\section{Kantian dignity}

\subsection{Resources in Kant}

Kant's work provides at least seven powerful resources for articulating the dignitarian perspective.

(i) First, dignity is a deontic status, a normative property of human beings consisting in their being entitled to certain types of respectful and helpful treatment. Kant's Formula of Humanity expresses the core moral idea, which underlies all duties, ethical and juridical. It enjoins you to "act so that you use humanity, whether in your own person or in the person of any other, always at the same time as an end, never merely as a means" (G 4:429). ${ }^{3}$ We should shape our practices and institutions so that we do not

\footnotetext{
${ }^{3}$ A juridical expression is the duty of "rightful honor": "Do not make yourself a mere means for others but be at the same time an end for them." This "internal duty" has a correlative "external duty" to avoid wronging others (MS 6:236-7). Kant's works are referenced as follows. WA= "An Answer to the Question, 'What is Enlightenment?"” (in Kant 1996a). G = Groundwork to the Metaphysics of Morals (Kant 1996a). KpV =Critique of Practical Reason (Kant 1996a). TP = "On the
} 
treat people with malice, with indifference, or by taking them as mere tools. ${ }^{4}$

Importantly, this notion of dignity differs from other, convention-based status ones. It does not designate the fact of being seen as having certain claims within certain cultural or legal codes. Kant's distinction between natural and positive right helps to see this point. There are natural rights which people may have even if there are no legal statutes stating them. In fact, it may be a requirement of natural right that some such legal scheme be created in order to render the various first-order natural rights more determinate and their enjoyment more secure. ${ }^{5}$ The dignitarian status is deeper and provides critical leverage to assess conventional codes.

(ii) Second, Kant presents dignity as an inherent status with universal scope. This is a novel idea of human dignity, of an "inner worth" 6 possessed by human being as such. Dignity is based in persons' capacities for practical reasoning, including those for technical, prudential, and especially moral deliberation. It is not a matter of their praiseworthy acts, their social class or their nationality. Thus, human dignity grounds universal human rights — entitlements people have against anyone who can affect them, whoever they are and wherever they are situated in social space. ${ }^{7}$

(iii) Dignity is also an egalitarian status. It is held by human persons in virtue of general features of them, and not due to any social rank within existing social structures. A person with dignity "can measure himself on a footing of equality" with "all other rational beings in the world" (MS 6:435).

(iv) Dignity has great normative force. As an "unconditional, incomparable worth," it generates rights

common saying: That May Be Correct in Theory, But It Is of no Use in Practice" (Kant 1996a). $\mathrm{R}=$ Religion within the Boundaries of Mere Reason, in Kant, Religion and Rational Theology (Kant 1996b). EF = "Toward Perpetual Peace" in Practical Philosophy. MS = The Metaphysics of Morals (Kant 1996a).

${ }^{4}$ Kant clearly identifies dignity as a deontic status when he presents it as "consisting in" human beings' entitlement to positive telic and not merely instrumental treatment (MS 6:462 - see 434-5). He introduces with dignity a distinctive sense of "value" which, as a kind of "standing," is not reducible to the traditional sense of "being good." Parfit (2011: sect. 35).

${ }^{5}$ EF 8:355-6, 378; MS 6:305-8, 311-2, 354-6. Kant distinguishes between natural and positive rights, claiming that juridical statutes stating the latter must track the moral claims involved in the former (MS 6:224, 229, 237, see also 291). The further divisions in the Doctrine of Right identify the aspects of natural rights.

${ }^{6} \mathrm{G}$ 4: 434 .

${ }^{7}$ See discussion on cosmopolitan right (EF 8:349-51). Kant uses "humanity" (a) narrowly comprising the capacity to set oneself ends (R 6:26-8), and (b) more broadly including also the capacity to morally assess one's actions and attitudes (MS 6:386-7). I focus on (b). 
and duties that have priority over competing considerations. Human dignity is "above any price". ${ }^{8}$ What is owed to someone in accordance with their dignity has priority over agents' existing desires and over cultural or legal conventions. $^{9}$

(v) The various norms specifying how to appropriately respond to persons' dignity have a wide site of application. Some focus on outer behavior, others on internal attitudes; some focus on coercively enforceable acts, others on behavior that cannot or should not be enforced externally; some specify duties attached to roles within certain institutions, others hold generally.

In the systematic account of the Metaphysics of Morals, Kant distinguishes between fundamental principles and principles of application (MS 6: 216-7, 411). The fundamental requirement is to preserve and promote human beings' rational freedom (the basis of their dignity). The Doctrine of Right articulates that requirement as it applies to agents' external actions that are appropriately subject to coercion (MS 6:230-1, 237). To justify laws and policies, this doctrine deploys a Principle of Right stating that persons may only act in ways that are compatible with others being permitted to act in the same ways (MS 6:230) and a Social Contract Standard requiring lawgivers to only impose rules which all those subject to them could rationally accept (TP 8:297; EF 8:350-1; MS 6:313-5). In the case of the Doctrine of Virtue, the fundamental requirement is the categorical imperative as supreme obligation of virtue (MS 6:395), which is further specified through various obligatory ends shaping agents' maxims (MS 6:395, 468-9). ${ }^{10}$

(vi) We must distinguish between the most general and fundamental dignitarian principles and their application as specific requirements for institutions, maxims, and choices. The latter address the circumstances of dignity, taking into account relevant empirical claims about human beings' nature and

\footnotetext{
${ }^{8}$ G 4:434-6; see G4:439; MS 6:434-6, 6:462, 483.

${ }^{9}$ Morality ought to frame and guide law and politics (EF 8:370-80).

${ }^{10}$ The existence of a framework of coercive law, and its specific requirements, must be defended with moral arguments (Guyer 2014: 277, 285). Interpreters disagree as to whether Ethik and Recht are radically discontinuous. Like Guyer (2014: 276-86), I emphasize continuity. Ethics and right (Ethik and Recht) are two branches of morality (Moralitaet, Sitten) (MS 6:214; EF 8:385-6) articulating the same core dignitarian concerns for different sites of application.
} 
social condition in more or less historically specific contexts. ${ }^{11}$ Besides identifying occasions for their application, empirical considerations help assess the feasibility of dignitarian norms. It is warranted to believe that we can act in the ways we ought to act. But we also want to know how likely are we to succeed if we endeavor to act in those ways. Various psychological and social mechanisms may affect our eventual paths. A responsible pursuit of moral dignitarian projects that is normatively ambitious but not naïve should take empirical inquiry into these mechanisms very seriously. ${ }^{12}$

(vii) Kant emphasizes the importance of freedom, praising "the idea of the dignity of a rational being, who obeys no law other than that which he himself at the same times gives". ${ }^{13}$ Respect for freedom is central to dignitarian treatment. Thus, support for others must proceed in such a way that the capacity for self-governance is engaged rather than circumvented or belittled. If we help others, we should contribute to their pursuit of happiness as they see it, not as we see it (so long as their plans are not immoral) ${ }^{14}$. In politics, governmental action should avoid paternalism. ${ }^{15}$

(viii) Finally, and relatedly, Kant underscores the importance of the capacity for moral reasoning. He sharply distinguishes human beings' capacities for moral, prudential, and technical reasoning, taking the first to constrain the others. Moral reasoners have a distinctive dignity. ${ }^{16}$ They can engage in introspective or intersubjective deliberation and decision-making that track impartially the good of all.

Autonomy as the capacity for moral reasoning is "the ground of the dignity of human nature" (G: 436). It is presupposed by the telic treatment the Formula of Humanity requires. "[T]he will of a rational being must always be regarded as at the same time lawgiving, since otherwise it could not be thought as

\footnotetext{
${ }^{11}$ Thus, in the Doctrine of Right, property rights assume that human beings live in a finite space (the earth) in which they are bound to affect each other. In the Doctrine of Virtue, the duties to oneself regarding the preservation and development of one's intellectual and moral powers assume that one is tempted to pursue short-term satisfaction and let them rust. Guyer (2014: 44, 288-9, 293, 314-6).

12 Thus, "Perpetual Peace" combines ambitious global norms with shrewd remarks on how people might join international peaceful cooperation out of self-interested motives of fear and commercial gain.

${ }^{13} \mathrm{G} 4: 434$.

${ }^{14}$ MS 6:454. See 388, 450.

15 TP 8:290-1, 298; MS 6:318.

16 " $[\mathrm{M}]$ orality is the condition under which alone a rational being can be an end in itself, since only through this is it possible to be a lawgiving member of the kingdom of ends. Hence, morality, and humanity insofar as it is capable of morality, is that which alone has dignity" (G 4:435).
} 
an end in itself." 17 The relation between appropriate treatment and autonomy is also envisioned in the Formula of the Realm of Ends of the moral law, which presents an ideal social world as "a systematic union of rational beings through common objective laws, that is, a realm [Reich], which can be called a realm of ends (admittedly only an ideal) because what these laws have as their purpose is just the relation of these beings to one another as ends and means" (G 4:434; translation amended). This formula presents an intersubjective rendering of the Formula of Autonomy based on "the idea of the will of every rational being as a will giving universal law" (G 4:431).

Discovering on what terms others could rationally will us to treat them gives us crucial information to figure out how we should treat them. We do not treat them inappropriately if they could rationally endorse the terms on which we treat them. This point has its political articulation in the Social Contract Standard-“" an idea of reason, which, however, has its undoubted practical reality, namely to bind every legislator to give his laws in such a way that they could have arisen from the united will of a whole people and to regard each subject, insofar as he wants to be a citizen, as if he has joined in voting for such a will" (TP 8:297).

Because of the supreme importance of moral reasoning, we can give a sharp defense of rights to participate in political decision-making, and to actually shape that process in a deliberative way. We can also explain more clearly why, when identifying the conditions and goods people have a right to access, we should include those supporting agents' autonomy besides their happiness.

\subsection{Difficulties and revisions}

Kant's views on dignity are not without problems. This section identifies three important difficulties and suggests some revisions, which develop the Kant-inspired dignitarian account in new ways.

(i) Narrow view of the basis of dignity. Kant fails to capture all that is intrinsically valuable in human beings and makes them worthy of treatment that is respectful and helpful. According to Kant, the ground

${ }^{17} \mathrm{G} 4: 434$. 
of dignity is rational agency, including the capacity to set ends and, especially, the capacity for autonomous reasoning about what is morally right. ${ }^{18}$ But we should be more sensitive and adopt a broader view. Certain capacities for practical reasoning falling short of moral reasoning are significant in their own right. And the same is the case with sentience. We rightly pay attention to them, for example, when considering how healthcare practitioners should treat patients with severe cognitive impairments. Medical treatment here could not go very far in terms of recruiting patients' rational endorsement, but should still respond to any level of agency that is present and be directly concerned with limiting their misery and facilitating pleasant experiences. Furthermore, a broader view is intuitively more plausible because it would enable recognition of the dignity of non-human animals and the direct duties owed to them. It is implausible to uniformly lump together every entity that is not a "person" with moral agency into the ontological heap of "things". ${ }^{19}$

(ii) Insufficient recognition of the importance of well-being. As Kant says, we must respect persons' freedom. But norms to foster their well-being are important as well, even if they must be constrained by (or at least weighted against) norms not to hamper their freedom. Kant's use of the phrase "dignity" is however tied to duties of respect for freedom, and not explicitly linked to concern regarding well-being.

Now, duties of concern regarding people's well-being can (and I think should) be seen as part of what dignitarian norms include. A direct concern for well-being is already involved in Kant's recognition of the positive dimension of the Formula of Humanity ${ }^{20}$ and in his defense of duties of beneficence, which precisely focus on furthering other agents' happiness. ${ }^{21}$ Additionally, Kant's conception of the "highest

${ }^{18}$ G 4:428-9, 434-6; KpV 5:87-8; MS 6:434-5, 442-4.

19 The dignity of human beings need not only include what makes them different from other animals. The key point is to identify a status that individual human beings have independently of their membership of a nation, class, and other groups they sometimes invoke to harm or ignore each other's freedom and well-being.

20 " $[\mathrm{H}]$ umanity might indeed subsist if no one contributed to the happiness of others but yet did not intentionally withdraw anything from it. But there is still only a negative and not a positive agreement with humanity as an end in itself unless everyone also tries, as far as he can, to further the ends of others. For the ends of a subject who is an end itself must as far as possible be also my ends, if that representation is to have its full effect in me" (G 4:430; see also MS 6:395). For systematic discussion, see Gilabert (2010).

${ }^{21}$ MS 6:385, 393-4, 452ff. 
good," the ultimate object of morality, includes both happiness and virtue. This conception may be interpreted as saying that (a) well-being is significant as an ethical aim even though (b) it is constrained by another significant aim that has strict priority—achieving moral virtue. ${ }^{22}$

Even if we accept Kant's critique of paternalism in politics, we do not thereby have to dismiss the importance of happiness for political choice. When we make an autonomous collective choice, we must ask ourselves which amongst the available set of options is best. A natural way to proceed - I do not say the only one - is to choose the set that will make us happier-insofar as no injustice is thereby generated. Regarding persons as ends in themselves includes taking their happiness as significant. ${ }^{23}$

Why should well-being matter within a dignitarian framework? My hypothesis is that well-being (at least in part) coincides with the development and exercise of the capacities that give rise to human dignity. Whether we adopt an objectivist, desire-satisfaction, or hedonistic view of well-being (or some combination thereof), states of well-being are likely to feature in the conditions protected and promoted by the fulfillment of dignitarian norms. On an objectivist account (which I favor), well-being involves access to intrinsic goods, which could include the development and exercise of various valuable human capacities. Success in this development and exercise could involve the satisfaction of informed desires of the kind desire-satisfaction theories center on. And, finally, the enjoyment that comes with these developments and exercises of capacities are of the kind a hedonistic theory might praise (and might, additionally, be highlighted by an objectivist theory that takes pleasure as one of the items in its list of goods - perhaps because of the value of the capacity of sentience or because enjoyment is constitutive of what it is to develop and exercise capacities well).

So, by adding a more explicit and positive focus on supporting people's pursuit of their well-being to

${ }^{22}$ KpV 5:109-10. Parfit (2011: ch. 10). I use "happiness" and "well-being” as equivalent. Kant does so too (e.g. MS 6:452). Kant often endorses a hedonistic view of well-being as contentment with one's life (KpV 5:22, 60-1; MS 6:452, 480). He occasionally construes it along a desire satisfaction view, as "the satisfaction" of a "system" of "inclinations" (KpV 5:73, 124).

${ }^{23}$ See KpV 5:110. Furthermore, using the options acquired to "enjoy life" is part of what taking oneself as an end calls for. Kant rightly criticizes "miserly avarice," the maxim of amassing resources (and with them options) without using of them to bring about enjoyment (MS 6:432-3). 
the respect and promotion of their freedom we do not only complement what Kant explicitly says about the targets of moral action and institutions. We also develop the dignitarian framework by showing how it generates concern for well-being as a dimension of appropriate responses to status-dignity. Well-being is part and parcel of dignitarian morality, not a concession it grudgingly makes to objectors. An important corollary for a theory of rights is that there is no insurmountable gap in moving from interests in wellbeing to rights to access it when the former concern the development and exercise of the capacities in the basis of dignity which ground the deontic space of rights itself. The capacities at the basis of dignity bridge the gap by simultaneously grounding interests in, and rights to, their development and exercise.

Now, if we accept this broader dignitarian outlook, we must see social, legal, and political philosophy as asking what, if anything, might justify the coercive imposition of constraints on people's choices regarding external action, but also how people's well-being might justifiably be fostered. A theory of justice can, pace one of Kant's observations, focus on needs besides choices (MS 6:230). Thus, I suggest that we interpret the Social Contract Standard as allowing us to draw on shareable reasons of well-being when assessing alternative social institutions, laws, and policies. We do not need to rely only on the normative idea of being one's own master and avoiding submission to the will of others (MS 6:238). In fact, we need to appeal to something else if we are to figure out what to choose (together) as the appropriate terms of our social life. ${ }^{24}$ And notions of well-being linked to the development and exercise

\footnotetext{
${ }^{24}$ An application of the Social Contract Standard based on considerations of well-being, or on the real freedoms or capabilities to achieve various forms of well-being might pit that standard against the Principle of Right. Although this conflict is not necessary, when it arises (i.e. when some types of act that could be consistently available to all are prohibited) we might conclude that, all things considered, some deliverances of the formal test of the Principle of Right can be overridden. Another option is to constrain that test so that it applies only after the range of important liberties is determined (perhaps drawing, in part, on considerations of well-being). Thus, I side with Rawls in the contrast between his and Kant's approaches to justice as depicted by Ripstein (2009: 3-6). Ripstein says that Kant does not focus on how to fairly distribute the burdens and benefits of social cooperation because he is concerned with the different, formal issue of justifying social frameworks that do not violate people's right to be their own master. If appropriately responding to people's dignity requires fostering their wellbeing (in freedom-respecting manners), then how each should contribute to this fostering is a crucial question indeed. One reason why we should accept (impartially selected and implemented) constraints on our economic choices would be, precisely, that such constraints might foster people's well-being. As Rawls (2001; sect. 32) realizes, we need to choose between different possible but incompatible bundles of liberties, and not every conceivable liberty should be enshrined in principles of justice (even if they could be simultaneously available to all). A substantive argument is needed to identify what liberties should be defended, and the conditions for their effective exercise should be identified as well. Thus, some economic liberties to engage in capitalist relations of production do not have the moral importance of freedom of speech, religion, and political activity,
} 
of capacities that give rise to human dignity fit the bill quite nicely. Kant already draws on considerations of this kind in his ethical doctrine. Saving the differences, it could also be done at the level of the doctrine of right. Or so a full development of the dignitarian approach that includes the ideal of Solidaristic Empowerment would, in my opinion, require.

(iii) Limits of independence. Kant affirms an idea of independence. He often construes it as selfdetermination, championing agents' ability to determine themselves to act on the basis of what their own prudential and moral reasoning recommends rather than on the basis of unchecked inclinations, ${ }^{25}$ or the opinions and dictates of others. ${ }^{26}$ The political expression is active citizenship ${ }^{27}$ and the rejection of paternalistic despotism. ${ }^{28}$ In other cases, Kant links independence with the idea of self-reliance, of not depending on others for the satisfaction of one's needs (except as a member of a state). ${ }^{29}$ This leads Kant to a qualified characterization of beneficence. The worry is that beneficence may be "humiliating" to the people helped. ${ }^{30}$ It is preferable that the rich help the poor anonymously, without humbling them or making them feel that they are put under obligation. Sometimes people fail to show gratitude because they fear this would signal their dependence on those who help them, and thus their inequality and perhaps lack of dignity. ${ }^{31}$

Kant is right to praise independence as self-determination. In recognizing this independence, we can indeed "feel [our] own dignity". ${ }^{32}$ Kant is also correct to challenge paternalism, and to spot the significant interaction between conditions of economic dependence and lack of active self-determination. I am less sure that we should accept his tendency to also affirm independence as self-reliance. Self-reliance seems

and could justifiably be restricted to secure the fair value of the latter liberties and to service other concerns such as fair equality of opportunity to participate in economic activity and the requirement that every participant (especially the worstoff) benefits from it.

${ }^{25} \mathrm{KpV}$ 5:117-9, 152, 269.

${ }^{26}$ MS 6:237-8.

${ }^{27} \mathrm{EF} 8: 350$. "[T]reatment of the human being" as free is "in keeping with his dignity" (WA 8:42).

${ }^{28}$ TP 8:290-15. Even in beneficence, helpers must refrain from imposing their own view of happiness (MS 6:454).

${ }^{29}$ G 4:434; TP 8:294-6; MS 6:237-8, 314-5.

${ }^{30}$ MS 6:448-9, 453.

${ }^{31}$ MS 6:459.

${ }^{32} \mathrm{KpV}$ 5:152. 
infeasible given our causal dependence on others to achieve most of what we value. And it seems undesirable to construe help as giving rise to humiliation, both because this would deter people from helping each other and thus from getting benefits they need, and because the practices of help could be in themselves valuable instances of telic treatment of persons. As socialists and feminists have argued after Kant, human beings are inescapably interdependent. To manage that interdependence properly, they should recognize solidarity as essential for achieving just social relations. The Kantian ideal of a realm of ends should include a combination of self-determination and solidarity in both interpersonal and institutional settings.

Perhaps these points can be reconciled through Kant's caveat that economic reliance on others is not a problem if the relation is under the framework of equal citizenship (where the poor are helped as citizens through public services based on general taxation by the government rather than as private persons assisted by other private persons). But even at the political level, citizens will have different amounts of actual power to affect governmental decision-making (some may be more charismatic, or more intelligent, or more knowledgeable, or part of the majority, etc.). Although we should aim at equal empowerment in politics, factual inequalities will remain. A morality of solidaristic use of unequal power seems necessary. ${ }^{33}$

A further point cuts deeper to show the limits of Kant's idea of independence as self-determination. If we only see the contours of a just society as constituted by the constraint that it should prevent dependence as the subjection to the choice of others, then we will not be fully able to respond to the value of people's capacities giving rise to their status-dignity. Two societies might be constructible in which nobody subject others to their will. But one may feature more opportunities, equally distributed, for all to achieve higher levels of development and exercise of their valuable capacities. A political conception

\footnotetext{
${ }^{33}$ To be fair to Kant, he recognizes that benevolence and gratitude may be appropriate even after extensive duties of right have been established, and he worries about the rejection of help that is based on wounded "pride" (MS 6:458).
} 
singly based in independence ${ }^{34}$ cannot explain why the first is preferable. A wider notion of empowerment is needed. This idea focuses on abilities to flourish in various ways, and is a fitting target for solidaristic action and institutions. This is the kind of thought that socialists have come to add since the $19^{\text {th }}$ century to the liberal concern with non-domination and formal equality of opportunity. A dignitarian framework can capture this move, but at the (reasonable) cost of going beyond the narrow construal of freedom as independence. This point works in cooperation with the call for more attention to the importance of well-being. And it can mobilize other resources in Kant's work, such as his postulate concerning property rights — stating that access to material resources is necessary for effective freedom (MS 6:230) — as a step in an argument calling for greater empowerment to develop and exercise one's valuable human capacities. We are already in socialist territory.

\section{Marxian Socialism}

\subsection{Capitalism and socialism}

We can go beyond Kant in identifying the radical social consequences of equal dignity. Besides criticizing feudalism and absolutism, we can challenge capitalism.

Although the idea of human dignity is the heart of his moral outlook, and he claimed that every human being has equal dignity, Kant did not identify all the radical implications of this idea for the shaping of social institutions and practices. ${ }^{35}$ For example, although Kant claimed that in a just society people would have equal formal opportunities to compete for economic advantages instead of being inescapably destined to certain positions such as lords or serfs, or masters and slaves, he also took this society to allow for great inequalities regarding income, wealth, and other economic advantages. We can go further and consider whether egalitarianism about status-dignity generates egalitarianism about access to economic advantage. A key task for a dignitarian perspective is to explore how equality regarding status-

\footnotetext{
34 e.g. Ripstein's (2009).

${ }^{35}$ Wood (2008: 194-5, 323-4 n.5).
} 
dignity should translate into various forms of condition-dignity_-bundles of equal civil, political, and social rights people should enjoy.

In this exploration, Marx's work provides important insights. With these insights, we can develop the dignitarian account to include a more direct normative focus on well-being besides autonomy, a greater awareness of the social and historical conditions for the fulfillment of dignitarian norms, a fuller understanding of why and how economic life is a crucial site for dignitarian analysis, a greater recognition of the importance of positive duties of solidarity, and a discovery of the phenomenon of ideology. This section discusses these insights by addressing two key Marxian themes: the critique of capitalism and the delineation of an alternative, socialist project. The Kantian dignitarian approach outlined in the previous section helps articulate these Marxian themes in original ways by providing an explicit normative structure which is not readily apparent in Marx's texts.

In the interpretive debates about the normative underpinnings of Marx's critique of capitalism and his advocacy for socialism, some have argued that Marx did, and others that he did not, have views about justice. I agree with Geras (1985) that Marx did hold quite strong views about justice even though he was not fully aware that he did so. ${ }^{36}$ I also agree with Geras that much of Marx's hostility to justice talk has to do with a specific (and in fact normatively fruitful) misgiving about proposals of social change that do not pay attention to feasibility considerations. Marx's work can help us explore the material and social conditions for the feasibility, and thus in part for the successful pursuit of a dignitarian project. The degree to which people succeed at becoming virtuous and happy partly depends on the social and material circumstances in which they act, and on what they do in response to them (including changing them over time). Much of our normative thinking should thus be focused on figuring out how to frame our reaction to our social and material circumstances. Interestingly, Kant's own work on politics, law,

\footnotetext{
${ }^{36}$ For the historical debates about Marxian socialism and Kantian morality, see Love ().
} 
and history did not ignore them. Marxists can take this exploration further (if they also overcome a selfcontradictory wholesale rejection of normative inquiry).

The dignitarianism framework can be developed to yield dignitarian socialism. Before we proceed, we should have working definitions of capitalism and socialism, the two social systems on whose contrast Marx and socialists concentrate. It comprises three key points (I state them starkly, but each involves a possible continuum between more or less capitalist or socialist societies and various combinations):

1. In capitalism, the bulk of the means of production - the natural and technological resources workers use to produce — are privately owned and controlled. In socialism, the means of production are socially owned and controlled.

2. In capitalism, production is primarily oriented toward profit, while in socialism it is primarily oriented toward the satisfaction of needs.

3. In capitalism, a class division develops between capitalists and workers. Capitalists own means of production and most workers do not. To survive, workers must sell their labor power (which they fully own in capitalism as well as in socialism, unlike in slave or feudal societies) to capitalists, and work under their direction for a wage. Socialism dissolves this class division.

\subsection{The critique of capitalism}

Kant does not have much to say about the relationship between capitalist employers and waged workers. He does, however, critically discuss slavery and serfdom, saying that they could not rightfully emerge contractually. A contract of slavery would be self-contradictory, as someone who becomes a slave has lost all freedom and with it any duty to keep a contract. A contract of serfdom would also be problematic, as it would generate a relationship in which there are no determinate constrains on how much the lord can get out of the serf, so that the lord could use the serf up without their consent (MS 6:283, 330). Kant also explicitly mentions the importance of securing formal equality of opportunity by eliminating hereditary prerogatives (TP 8:292). He recognizes that this is compatible with significant economic inequalities of economic advantage, including that between employers and employees, and in fact finds 
such inequalities unproblematic so long as they reflect the talents and industry of those involved (TP 8:292-3). He even claims that those not holding property (including property-less workers) may be denied the right to vote because holding property is a precondition for being one's own master (TP 8:295, MS 6:313-5). So, Kant is far from offering a socialist analysis of economic inequality. ${ }^{37}$ On the other hand, Kant tempers this meritocratic acceptance of inequality of condition by also allowing for provisions of governmental assistance for poor people (MS 6:325-7). And, quite importantly, Kant recognizes, like Marx, that many problems are to be addressed first as a matter of how the structure of a society is organized rather than as a matter of the adoption of good attitudes by isolated individuals. The following remark on beneficence is one many socialists would endorse:

Having the resources to practice such beneficence as depends on the goods of fortune is, for the most part, a result of certain beings being favored through the injustice of the government, which introduces an inequality of wealth that makes others need their beneficence. Under such circumstances, does a rich man's help to the needy, on which he so readily prides himself as something meritorious, really deserve to be called beneficence at all? (MS 6:454; see KpV 5:155n.)

It is not that interpersonal instances of instrumental or telic treatment are not important. It is, rather, that there are structural instances of those kinds of treatment, and the forms of social relations they involve should be given pride of place in social critique and change because of their enormous symbolic and causal significance. Let me elaborate by considering the three main socialist charges against capitalism, which concern exploitation, domination, and alienation.

(i) Exploitation. In the technical Marxian sense, the exploitation of workers consists in the extraction of their surplus labor (the part of their work that goes beyond securing their own reproduction as workers).

\footnotetext{
${ }^{37}$ Even if it were true that to be one's own master one must have property (or, more plausibly, that having property increases the likelihood of successful self-determination), the theorem of a Kantian philosophy of freedom (which affirms the "innate equality" of all human beings as entitled to be their own masters-MS 6:237-8) should be to require widespread extension, or even socialist control, of productive assets so that every human being who could determine themselves does effectively come to enjoy such condition. Kant was clearly troubled by this issue: 'It is, I admit, somewhat difficult to determine what is required in order to be able to claim the rank of a human being who is his own master' (TP 8:295).
} 
Class societies involve exploitation. The immediate producers, the workers, engage in both necessary and surplus labor. The latter (or its product) is appropriated by the members of the dominant classes. Masters exploit slaves, lords exploit serfs, and capitalists exploit waged workers. ${ }^{38}$ Now, in ordinary language, "exploitation" has a normative connotation. One common rendering is that it consists in taking unfair advantage of others. The exploitation of workers involves a morally problematic transfer of valuable resources (such as the product of surplus labor) from them to their exploiters. But what renders the transfer morally problematic? On the account that I favor, exploitation is a form of wrongful use of superior power. ${ }^{39}$ It involves taking advantage of others who are weaker by getting them to give you more than they should.

Capitalists exploit workers by using their superior bargaining power (resulting from their private control of the means of production) to extract from them more than they might (and ought to) give if they were not so vulnerable. The Kantian dignitarian account explains what's wrong with this. One of the most evident ways in which capitalism is an affront to dignitarian ideals is that it enshrines instrumental treatment of others as a typical aspect of production and exchange. As the competitive economic agents that they are, capitalists seek profit, and show concern for the freedom and well-being of their workers only if, and to the extent that, doing so would add to their profit margin. Workers have price, not dignity, for them. This has a systemic dimension as well, as capitalists normally throw their significant weight behind political agents and processes that sustain institutional schemes that cement their privileged position by making capitalist relations of production the law of the land. Capitalist exploitation is a social

\footnotetext{
${ }^{38}$ The source of capitalist profit is the exploitation of labor. Labor power is a peculiar commodity: it can create more value than it costs. Its deployment can involve surplus labor besides necessary labor. The exchange value of labor power (expressed in a wage) is the amount of labor that is socially necessary to reproduce it over time. But workers normally work more time than is necessary to produce what they consume with their wages. Besides this necessary labor, they engage in surplus labor, the results of which are appropriated by the capitalists. Profit is based on surplus value- the difference between the value created by the use of labor power and the value of that labor power itself (as well as other costs of production) Marx (1990: 270-80, 293-306). We can state these points without relying on Marx's controversial theory of value by saying that workers create what has value rather than value itself (Cohen (1988: ch. 11). For exhaustive discussion of textual clues as to whether Marx condemned exploitation as unjust, see Geras (1985).

${ }^{39}$ Goodin (1987).
} 
pattern of reduction of some human beings to mere instruments for the self-regarding benefit of others.

(ii) Domination. It could be objected that capitalist exploitation involves no dignitarian injustice because workers freely consent to the terms on which they interact with capitalists. They are not, like slaves, dragged to the factory or the office against their will. They sign contracts. But this objection ignores that the exploitation of workers happens in tandem with their domination. Consent that is given in circumstances of profound vulnerability and power asymmetry does not authorize its outcomes.

For consider, how is it that workers acquiesce to their exploitation? How come they enter contracts in which they produce and give away objects with more value than is expressed in their wages? Is it because they want to altruistically sacrifice their own well-being to make sure that the capitalists live in luxury? According to Marx, two conditions help explain workers' choice to enter a contract of exploitation: (1) Workers in capitalism (unlike in feudalism or slave societies) own their labor power, but (2) they do not own means of production. Given their dispossession (2), workers have no reasonable alternative to using their entitlement (1) to sell their labor power to the capitalists — who do own the means of production. ${ }^{40}$ Because of the deep background inequality of power resulting from their structural position in a capitalist economy, workers accept a pattern of economic transaction in which they submit to the direction of capitalists during the activities of production and surrender a disproportional part of their fruits.

Again, Kant helps us understand what's wrong here. He deploys the radical idea of a human beings' "innate equality, that is, independence from being bound by others to more than one can in turn bind them; hence a human being's quality of being his own master" (MS 6:237-8). This idea has important consequences for the assessment of relations of production in capitalism, as these involve domination and the dependence of workers on the discretion of capitalists' choices at three critical junctures. The

40 Marx (1990: 272-3). Additionally, capitalism (through labor-saving technical innovations spurred by competition) constantly produces unemployment, which weakens the bargaining power of individual workers further. Thus, Marx says that although workers voluntarily enter the contract of exploitation, they are "compelled [to do so] by social conditions." "The silent compulsion of economic relations sets the seal on the domination of the capitalist over the worker.... [The worker's] dependence on capital ... springs from the conditions of production themselves, and is guaranteed in perpetuity by them." (Marx 1990: 382, 899). 
first is the one we have already considered, which concerns the labor contract. Due to their lack of control of means of production, workers must largely submit, on pain of starvation, to the terms capitalists offer them. The second concerns the day to day interactions in the workplace. Capitalists and their managers rule the activities of workers by unilaterally deciding what the workers produce and how they produce it. Although in the sphere of circulation workers and capitalists might look (misleadingly, given the first point) like equally free contractors striking fair deals, once we enter the "hidden abode" of production it is clear to all sides that what exists is relationships of intense subjection of some to the will of others. ${ }^{41}$ Workers effectively spend most of their waking hours doing what others dictate them to do. Third, and finally, capitalists have a disproportionate impact on the legal and political process shaping the institutional structure of the society in which they exploit workers-such as the contours of property and labor law. Even if workers manage to obtain the legal right to vote and create their own trade unions and parties (which labor movements have eventually achieved after much struggle), capitalists exert disproportionate influence via greater access to mass media, the funding of political parties, the threat of disinvestment and capital flight, and the past and prospective recruitment of state officials in lucrative jobs in their firms and lobbying agencies. At the spheres of exchange, production, and in the broader political process, workers are subject to the will of capitalists in the shaping of the terms on which they work. This is an affront to their dignity as self-determining, self-mastering agents. ${ }^{42}$

\footnotetext{
${ }^{41}$ Marx (1990: 279-80).

42 Also relevant is Kant's view of the initial appropriation of external resources (e.g. land) as a matter of social convention and as calling for a justification that tracks the general will of all those affected rather than only the convenience of unilateral appropriators (MS 6:258-270). Kant does not specify the terms on which a general will would authorize acts of appropriation or types of property (e.g. private or collective). Some interpreters warn that we should not assume that a general will authorization requirement would turn property into an instrument of public policy. The point of property is not to foster the well-being of those affected, but to respect individuals as independent, purposive agents. (Ripstein 2009: 154-5.) But it is not clear what the latter constraint really amounts to, or that a general will should not also have public policy aims. A dignitarian and socialist concern with the development and exercise of individuals' capacities would frame access to natural resources by recommending a scheme that services that concern. As such, this public aim could be both embraced by a general will and satisfy the abstract idea of respecting individuals' purposive agency. There is no general normative obstacle blocking a view of property in natural resources (and other means of production) as social devices to empower people to live free and flourishing lives. When defenders of capitalism protest, saying that socialized control limits the freedom of private agents, they must be reminded that "private ownership for some ... [involves] non-ownership ... for others" (Marx 1991: 948). Capitalist property rights set limits to the liberty of workers to access means of production. (Cohen 2011: ch. 7.) The freedom question when resources are scarce is what feasible scheme offers, overall, the greatest freedom for all.
} 
(iii) Alienation. The socialist critique of capitalism as a system of social relationships is complex. It also focuses on alienation. ${ }^{43}$ This critical point can also be fruitfully articulated in dignitarian terms.

Marx uses the term "alienation" to cover several phenomena. ${ }^{44}$ Subjectively, alienation can appear as a sense of lack of meaning or worth in one's life. But for Marx, alienation has an objective aspect. People may be alienated even if they do not feel alienated. The key is the mismatch between people's existencethe way they actually live their lives - and their essence. Alienation occurs when the former fails to appropriately express the latter. More specifically, in Marx's view, people are alienated when they do not develop and exercise the human capacities. Marx concentrates on those aspects of human nature relevant for productive activity, such as the capacities for freely chosen and creative work, which is undertaken in cooperative ways, and which meets the needs of others. ${ }^{45}$ Workers are alienated to the extent that their ability to develop and exercise these valuable capacities at work are limited. ${ }^{46}$ If, as seems plausible, these remarkable capacities are in the basis of dignity, then we can say that dignitarian norms are violated when workers are avoidably cornered in capitalism into work that is repetitive, stunting, toxically competitive, or that engages little initiative and decision-making.

When Kant discusses happiness, and the imperatives linked to its pursuit, he says that our inquiries would have to focus on figuring out empirically what causes happiness and then (conclude that we should) go for it. ${ }^{47}$ But this ignores that there is a substantive, non-analytic but also not merely empirical

${ }^{43}$ This passage captures the three charges discussed: "[W]ithin the capitalist system all methods for raising the social productivity of labour are put into effect at the cost of the individual worker; ... all means for the development of production undergo a dialectical inversion so that they become means of domination and exploitation of the producers; they distort the worker into a fragment of a man, they degrade him to the level of an appendage of a machine, they destroy the actual content of his labour turning it into a torment; they alienate from him the intellectual potentialities of the labour process in the same proportion as science is incorporated in it as an independent power; they deform the conditions under which he works, subject him during the labour process to a despotism the more hateful for its meanness; they transform his life-time into workingtime, and drag his wife and child beneath the wheels of the juggernaut of capital" (Marx 1990: 799).

${ }^{44}$ Elster (1986: ch. 3); Wood (2004: Part One); Wolff (2002: 28-39, 104-5, 122-5).

${ }^{45}$ Marx, 1844 Manuscripts, in Marx (1978: 75-7, 80-93); Marx (1990: 283-4).

${ }^{46}$ When alienated, "labour is external to the worker, i.e., it does not belong to his essential being; ... in his work, therefore, he does not affirm himself but denies himself, does not feel content but unhappy, does not develop freely his physical and mental energy but mortifies his body and ruins his mind. ... It is therefore not the satisfaction of a need; it is merely a means to satisfy needs external to it." (1844 Manuscripts, 74).

${ }^{47}$ G 4:418-9. As Parfit (2011: 243) and Wood (1999: 67, 365n.11) argue, Kant's moral theory lacks an account of non-moral goodness. 
or descriptive task of identifying certain ends in life as good, or as being constitutive of the agent's wellbeing. Marx's discussion of non-alienation and self-realization can be used to fill some of this gap. ${ }^{48}$ The Marxian view of self-realization says that people add to their well-being when they succeed at engaging in the free development and exercise of their human capacities in solidaristic cooperation with others. This view provides a partial account of the good worth plugging into our moral framework as part of the metric of advantage informing dignitarian norms. ${ }^{49}$ What we, individually or through our institutions, should not prevent others from accessing, or should enable others to access includes, inter alia, practices in which they can develop and exercise their capacities so as to achieve self-realization. These ideas inform Marx's characterizations of a socialist society. Self-realization would occur once the "realm of necessity" and the corresponding necessary labor to secure subsistence is circumscribed and people reach also a "realm of freedom" in which "the development of human energy which is an end in itself" unfolds. ${ }^{50}$ This realm of freedom would involve non-alienated labor. In fact, such labor, enabling the "all-round development of the individual," would become their "prime want." human emancipation featuring "the development of the rich individuality which is all-sided in its production as in its consumption" 52 and envision a "higher form of society in which the full and free development of every individual forms the ruling principle". ${ }^{53}$

\subsection{The socialist project}

How could the connection between the Kantian idea of equal dignity and the socialist views on socioeconomic justice be developed? We can envision the reshaping of socioeconomic relations so that they enact appropriate responses to the basis of the dignity of human beings involved in them. If people

\footnotetext{
${ }^{48}$ Kant claims that people should seek to develop their capacities (G 4:423).

${ }^{49}$ I agree with Wood (2004: 23-4) that we can interpret Marx's critique of alienation, and his ideal of self-realization, as relying on an objective conception of the good and of human happiness. As Wood (2004: 281, n.1) also points out, such a conception can be used in a theory of justice to provide information about what kinds of opportunities or conditions people can reasonably make claims to in their relations with each other.

${ }^{50}$ Marx (1991: 957-9).

51 “Critique of Gotha Program," in Marx (1978: 531).

52 Marx (1973: 325). See also German Ideology, in Marx (1978: 160).

53 Marx (1990: 739).
} 
have equal dignity because of some features of them, then social relations should be shaped so that these features are given the support they deserve in each person. Consider the predicament of working people. When they are dominated, and exploited, their capacities for self-direction and for cooperating as equals with others are insufficiently respected. They are treated merely as means. And workers are not treated as ends in themselves when the economy is (avoidably) organized so that some of them do not have real opportunities to develop and express their talents for creative and meaningful production — and are thus are alienated. Even if people have different (innate or acquired) talents, and as a result their efforts could not produce as much that is meaningful to them or others, they should still have equal chances to develop and exercise their valuable capacities and benefit from the contribution of others. This is what Dignitarian Socialism would suggest. As the flip side of the dignitarian critique of capitalism, it articulates Solidaristic Empowerment to recommend that we reorganize society so that it enables and supports each person's free development and exercise of their valuable human capacities.

(i) The Abilities/Needs Principle. Marx never provided a detailed account of what a socialist society would be like. In fact, he was hostile to advancing blueprints, dismissing this as a form of paternalism (see (ii) below). It is obvious that such a society would involve a shift to the socialist aspects of organization mentioned in the contrasts stated in section 3.1: the bulk of the means of production would be socially owned and controlled, production would primarily be aimed at need satisfaction, and the division between bourgeoisie and proletariat would disappear. These points are consistent with different specific institutional frameworks. Indeed, there is a lively contemporary debate showing that a centrally planned economy is far from the only option-for example, market socialism, the expansion of cooperatives, and the extension of democratic principles to the economy offer alternatives. ${ }^{54}$ Given space constraints, I concentrate here on a key idea by Marx, which is that socialist organization would

\footnotetext{
${ }^{54}$ Wright (2010).
} 
instantiate the slogan "from each according to their abilities, to each according to their needs" (the Abilities/Needs Principle). ${ }^{55}$

The Abilities/Needs Principle can be understood as an elaboration of the dignitarian idea of Solidaristic Empowerment. As I argue elsewhere, ${ }^{56}$ we can develop it in terms of the following demands:

(a) Opportunities for self-realization in work: There should be effective opportunities for productive activity involving self-realization rather than alienation. The available activities would foster the development and exercise of workers' productive capacities, give them powers of management, and enable them to cooperate. These opportunities would be effective in that mechanisms would be in place to offset morally arbitrary differences between workers that affect their accessibility. For example, excellent education would be available to all, and the workplace would be designed so that workers with different talents and bodily restrictions can thrive. These opportunities for activity involving selfrealization would meet a human need to engage in it.

(b) Positive duties: There should be a social ethos and institutions articulating positive duties to produce to meet other people's needs. Each should envisage some reasonable level of development and use of their powers to produce in this way.

(c) Securing basic needs: Some instantiations of the positive duties mentioned in (b) targeting the satisfaction of basic needs for subsistence and for being able to function as a political equal have especial urgency.

(d) Fair reciprocity: There should be an ethos and a scheme of distribution of access to consumption goods that recognizes a responsibility to cooperate in production on terms of fair reciprocity. Nobody should take advantage of cooperative efforts of others without making their own, similar effort if they

\footnotetext{
55 "In a higher phase of communist society, after the enslaving subordination of the individual to the division of labour, and therewith also the antithesis between mental and physical labour, has vanished; after labour has become not only a means of life but life's prime want; after the productive forces have also increased with the all-round development of the individualonly then can the narrow horizon of bourgeois right be crossed in its entirety and society inscribe in its banner: From each according to his ability, to each according to his needs!" ("Critique of Gotha Program," 531).

${ }^{56}$ Gilabert (2015: 207-8).
} 
can. Similar effort is not equivalence in output (which might depend on morally arbitrary differences in native endowments), but a matter of the proportion of contribution given one's abilities. Those (but only those) who make an equal effort (when they can) should have equal access to consumption goods. (e) Sensitivity to individual differences: Individual differences in abilities and needs are important. The assessment of levels of contribution should be mindful of differences in ability. And people should be able to pursue their well-being in ways appropriate to their singular characteristics. For example, they should be able to make their own choices concerning self-realization, consumption, and leisure.

The Abilities/Needs Principle helps envision an economy of mutual affirmation amongst all producers and consumers. It takes the abilities and needs of all as the focus of negative and positive duties. As a result, it gives human dignity full recognition. Importantly, this vision combines freedom and solidarity. This, I think, is a Kantian point. Kant's moral philosophy obviously affirms rights concerning individual and collective liberty. But it also affirms duties to contribute to the freedom and well-being of others. ${ }^{57}$ With the refinements proposed here, the Kantian dignitarian framework can escape the scorn Marx directed at the "Robinsonades" of modern political theory. ${ }^{58}$

(ii) Self-emancipation. Some Kantians could criticize the view just outlined by saying that it risks a paternalistic imposition on workers of work they might not choose, even if it would involve selfrealization. In response, notice four points. First, people are given real opportunities to engage in nonexploitative, non-dominating, and non-alienating labor; they are not forced to do so. The scheme empowers workers; it does not force them into any final state. Second, the shaping of the economy would be subject to democratic authorization and contestation. Enjoying robust political liberties, people could collectively assess and reform economic arrangements of the kind proposed. Third, we should

\footnotetext{
${ }^{57}$ We should develop our powers and make ourselves "a useful member of the world" (which also "belongs to the worth of humanity in [our] own person, which [we] ought not to degrade" (MS 6:446)).

${ }^{58}$ Marx (1973: 83-5) rails against failures to capture the extent to which people are socially dependent on each other. He argued that "[i]ndividuals producing in society—-hence socially determined individual production —is ... the point of departure" and that the "independent, autonomous subjects" of many $18^{\text {th }}$ century theories are "Robinsonades," "illusions."
} 
acknowledge that any society that has not completely eliminated material scarcity will need, and press, people to work. If this is so, it is only fair that they have opportunities to work in ways that engage rather than stunt their valuable capacities for free and cooperative production. Finally, the interest in the good of self-realization is linked to some of the capacities that give rise to status-dignity, and thus to the normative platform from which the paternalism objection itself draws its argumentative force. Responding to the dignity of people includes supporting their pursuit of a well-being involving the development and exercise of their valuable human capacities.

Despite popular misperceptions, Marx, and socialists inspired by him, are quite hostile to paternalism. This is partly why, for example, Marx was hostile to developing detailed recipes for how socialist transformation should proceed. He thought that "the emancipation of the working class must be the work of the working class itself," 59 and that this self-emancipation would likely exhibit a radical democratic form (as his praise for the Paris Commune suggests). ${ }^{60}$

(iii) Ideology and socialist politics. Also important for the Marxian view of politics is the critique of ideology, of attempts to shape the culture of a society so that the domination of some by others is deemed acceptable. Typical of ideologies is the presentation of the contingent as necessary, the historical as natural, and the conflictive as harmonious. ${ }^{61}$ Ideology critique has a role in dissolving these constructions. It shows that, often, what is presented as being in the general interest of all in fact only serves the particular interest of the dominant class. Interestingly, this operation can work in tandem with the Social Contract Standard. We can see socialist politics as a radical democracy in which people engage in public debate to figure out together what the idea of the social contract would really amount to for them, and decide by themselves what to do about economic justice.

\footnotetext{
59 “Letter to Bebel, Liebknecht, Bracke," in Marx (1978: 555).

${ }^{60}$ Civil War in France, in Marx (1978: 634-6).

${ }^{61}$ Marx (1973:87-8); German Ideology, 172-5; Manifesto of Communist Party (in Marx 1978), 487; $1990: 102-3$.
} 
Ideology critique can even target deployments of the idea of dignity in capitalism which dissociate it from solidarity. Marx in fact criticized conceptions that mischaracterize non-instrumental support for fellow human beings as involving "humiliation" and "an offence against the dignity of man" while condoning their treatment as commodities as "the justified, self-confident and self-acknowledged dignity of man incarnate". ${ }^{62}$ In opposition to a view of dignity that embraces possessive individualism to legitimize the social power and disproportionate benefits enjoyed by the rich, the lucky, and the strong, socialists put forward a more humane project that relies on generally shareable reasons to have opportunities for the free and cooperative development and exercise of our capacities, to be offered support by others when we need it, and to give it when we can. This project charts a fitting practical horizon for the hope that human dignity always inspires. ${ }^{63}$

\section{References}

Cohen, Gerald (1988). History, Labour, and Freedom. Oxford: Oxford University Press.

Cohen, Gerald (2011). On the Currency of Egalitarian Justice. Princeton: Princeton University Press.

Elster, Jon (1986). An Introduction to Karl Marx. Cambridge: Cambridge University Press.

Geras, Norman (1985). “The Controversy about Marx and Justice,” New Left Review I/ 150, 47-85.

Gilabert, Pablo (2010). "Kant and the Claims of the Poor.” Philosophy and Phenomenological Research 81, 382418.

Gilabert, Pablo (2015). “The Socialist Principle 'From Each According To Their Abilities, To Each According To Their Needs'.” Journal of Social Philosophy 46, 197-225.

Gilabert, Pablo (forthcoming) Human Dignity and Human Rights. Oxford: Oxford University Press.

Goodin, Robert (1987). "Exploiting a Situation and Exploiting a Person.” A. Reeve, ed., Modern Theories of Exploitation. London: Sage, pp. 166-200.

62 “Excerpts from Mill's Elements on Political Economy," in Marx (1992: 276).

${ }^{63}$ We should "develop the original predisposition to a good will within [us], which can never be lost" (MS 6:441).

For comments and conversations, I thank a referee, Rainer Forst, Kristen Hessler, Jon Mandle, Howard Williams, Lea Ypi, and audiences at the London School of Economics and SUNY Albany. 
Guyer, Paul (2014). Kant, $2^{\text {nd }}$ ed. New York: Routledge.

Kant, Immanuel (1996a). Practical Philosophy. Cambridge: Cambridge University Press.

Kant, Immanuel (1996b). Religion and Rational Theology. Cambridge: Cambridge University Press.

Love, Suzanne (2017). "Kant after Marx,” Kantian Review 22.4.

Marx, Karl (1973). Grundrisse. London: Penguin.

Marx, Karl (1978). The Marx-Engels Reader, ed. by R. Tucker, $2^{\text {nd }}$. Ed. New York: Norton.

Marx, Karl (1990). Capital I. London: Penguin.

Marx, Karl (1991). Capital III; London, Penguin.

Marx, Karl (1992). Early Writings. London: Penguin.

Parfit, Derek (2011). On What Matters. Oxford: Oxford University Press, vol. 1.

Rawls, John (2001). Justice as Fairness. A Restatement. Cambridge, MA: Harvard University Press.

Ripstein, Arthur (2009). Force and Freedom. Cambridge, MA: Harvard University Press.

Wolff, Jonathan (2002). Why Read Marx Today? Oxford: Oxford University Press.

Wood, Allen (1999). Kant's Ethical Thought. Cambridge: Cambridge University Press.

Wood, Allen (2004). Karl Marx, $2^{\text {nd }}$ ed. New York: Routledge.

Wood, Allen (2008). Kantian Ethics. Cambridge: Cambridge University Press.

Wright, Erik (2010). Envisioning Real Utopias. London: Verso. 